\title{
Ongoing Lung Inflammation and Disease Progression in Mice after Smoking Cessation
}

\section{Beneficial Effects of Formyl-Peptide Receptor Blockade}

\author{
Giovanna De Cunto, Barbara Bartalesi, Eleonora Cavarra, Emilia Balzano, Giuseppe Lungarella, and Monica Lucattelli
}

From the Department of Molecular and Developmental Medicine, University of Siena, Siena, Italy

\author{
Accepted for publication \\ June 18, 2018. \\ Address correspondence to \\ Monica Lucattelli, Ph.D., \\ Department of Molecular and \\ Developmental Medicine, \\ University of Siena, via Aldo \\ Moro n. 2, 53100 Siena, \\ Italy. E-mail: monica. \\ lucattelli@unisi.it.
}

\begin{abstract}
The most important risk factor for chronic obstructive pulmonary disease (COPD) is cigarette smoking. Until now, smoking cessation (SC) is the only treatment effective in slowing down the progression of the disease. However, in many cases SC may only relieve the airflow obstruction and inflammatory response. Consequently, a persistent lung inflammation in ex-smokers is associated with progressive deterioration of respiratory functions. This is an increasingly important clinical problem whose mechanistic basis remains poorly understood. Available therapies do not adequately suppress inflammation and are not able to stop the vicious cycle that is at the basis of persistent inflammation. In addition, in mice after SC an ongoing inflammation and progressive lung deterioration is observed. After 4 months of smoke exposure mice show mild emphysematous changes. Lung inflammation is still present after SC, and emphysema progresses during the next 6-month period of observation. Destruction of alveolar walls is associated with airways remodeling (goblet cell metaplasia and peribronchiolar fibrosis). Modulation of formyl-peptide receptor signaling with antagonists mitigates inflammation and prevents deterioration of lung structures. This study suggests an important role for $\mathrm{N}$-formylated peptides in the progression and exacerbation of COPD. Modulating formyl-peptide receptor signal should be explored as a potential new therapy for COPD. (Am J Pathol 2018, 188: 2195-2206; https://doi.org/10.1016/j.ajpath.2018.06.010)
\end{abstract}

Chronic obstructive pulmonary disease (COPD) is characterized by progressive obstruction of airflow, not fully reversible, which is accompanied by a chronic inflammatory response, induced by deleterious particles or gases, in airways and lung parenchyma. ${ }^{1}$ The most important risk factor for COPD is cigarette smoking. ${ }^{2}$ COPD is a collection of conditions, which include emphysema, chronic bronchitis with mucus hypersecretion, bronchiolar and vascular remodeling, and sometimes the presence of fibrotic areas scattered throughout the parenchyma, in which emphysema and fibrosis may coexist. There are currently no specific COPD treatments, and smoking cessation (SC) remains the most effective therapeutic intervention in patients with COPD. ${ }^{3}$ However, in many cases SC may only relieve the airflow obstruction and inflammatory response. ${ }^{4,5}$ Several studies in humans and animal experiments have demonstrated that, once COPD is initiated, the pulmonary inflammatory response continues ${ }^{5-7}$ and the enlarged alveolar airspace cannot be reversed after SC. ${ }^{8}$ Thus, persistent lung inflammation associated with a progressive deterioration of respiratory function (progressive decline in forced expiratory volume in 1 second) and infections in ex-smokers are an increasingly important clinical problem whose mechanistic basis remains poorly understood.

Studies on mouse models of cigarette smoke (CS) identified several mechanisms by which COPD lesions may be induced. ${ }^{9,10}$ These include the activation of the innate and adaptive immune responses ${ }^{11,12}$ that can lead to enhanced protease/antiprotease $^{13,14}$ or oxidant/antioxidant imbalances $^{15-17}$ in lung tissue with alveolar wall degradation.

Supported by MIUR grant 2008T5BLWA (G.L.) and University of Siena grant 122004 (M.L.).

Disclosures: None declared. 
The precise relationship between smoking, immune modulation in the lung, and respiratory infections is still the object of investigation because bacterial and viral infections may be critical in the induction of acute exacerbations in later COPD stages. ${ }^{18}$

In general, available therapies do not adequately suppress inflammation, and even inhaled corticosteroids, although effective in asthma, reduce exacerbations only to a certain extent in COPD and do not seem to reduce disease progression. ${ }^{19}$ In addition, new classes of drugs, such as phosphodiesterase- 4 inhibitors, can prolong the time between re-exacerbations ${ }^{20}$ but are not potentially able to stop the vicious cycle at the basis of persistent inflammation that characterizes and influences the various clinical stages of the disease.

Much of the current knowledge on the pathogenic mechanism(s) implicated in COPD derives from studies performed on several experimental animal models and in particular on smoking mice, which are able to replicate several features of human COPD. ${ }^{10,21-23}$ It was demonstrated that genetic ablation of the formyl-peptide receptor-1 $(F P R I)$ gene in mice or treatment with specific antagonists of FPRs prevents recruitment of inflammatory cells in the lung and confers protection from smoking-induced lung emphysema. ${ }^{24}$ These receptors, overexpressed in patients with COPD ${ }^{25}$ have been recently involved, together with mitochondrial formylated peptides, also in acute lung inflammation and injury. ${ }^{26}$

In this context, by using a curative experimental model of CS-induced pulmonary changes that is currently used in preclinical studies ${ }^{27}$ the ongoing lung inflammation and deterioration that follows $\mathrm{SC}$ was studied as well as the role of (FPR) signaling in the persistency of inflammation. The modulation of FPR-related signaling in mice halts chronic inflammation and prevents the deterioration of alveolar structures and the remodeling of airways that follow SC in mice. It is widely accepted that the enlargement of alveolar airspaces and the remodeling of small airways induced by
CS constitute the pathologic basis of airflow obstruction in COPD patients. ${ }^{28,29}$

\section{Materials and Methods}

\section{Animal Experiments}

Male C57Bl/6 mice (4 to 6 weeks old) used in this study were purchased from Charles River (Calco, Italy). The mice were housed in an environment controlled for light (7 $\mathrm{AM}$ to $7 \mathrm{PM})$ and temperature $\left(18^{\circ} \mathrm{C}\right.$ to $22^{\circ} \mathrm{C}$ ); food (Mucedola Global Diet 2018; Harlan, Correzzana, Italy) and water were provided for consumption ad libitum. All animal experiments were conducted in conformity with the Guiding Principles for Research Involving Animals and Human Beings $^{30}$ and were approved by the Ethics Committee of the University of Siena.

\section{Exposure to CS}

Mice from each experimental group were exposed to either room air or to the smoke of three cigarettes per day, 5 days per week for $4,6,8$, and 10 months (Virginia filter cigarettes, $12 \mathrm{mg}$ of tar and $0.9 \mathrm{mg}$ of nicotine). The methodology for smoke exposure has previously been described indetail. $^{31}$

\section{Experimental Design}

The scheme of animal treatments is reported in Figure 1. The day of the start of the study was defined as day 0 , allowing the association of this time point with the schedule of smoke cessation and compound administration. Several groups of mice were used in this study and sacrificed at 4, 6, 8, and 10 months from the start of the experiment. Group 1 includes control mice exposed to room air.

Group 2 includes mice exposed to CS and then sacrificed at day 8 after 4 months, and at 6,8 , and 10 months from the

\section{Smoke cessation and FPRs inhibitors treatment employing therapeutic strategy}

\section{Time in months (from the start of the study) \\ Group 1: air-exposed \\ Group 2: CS-exposed \\ Group 3: $\quad \mathrm{CS}+\mathrm{SC}$ \\ Group 4: $\mathrm{SC}+\mathrm{Boc} 2$ \\ Group 5: $\mathrm{SC}+\mathrm{CsH}$}
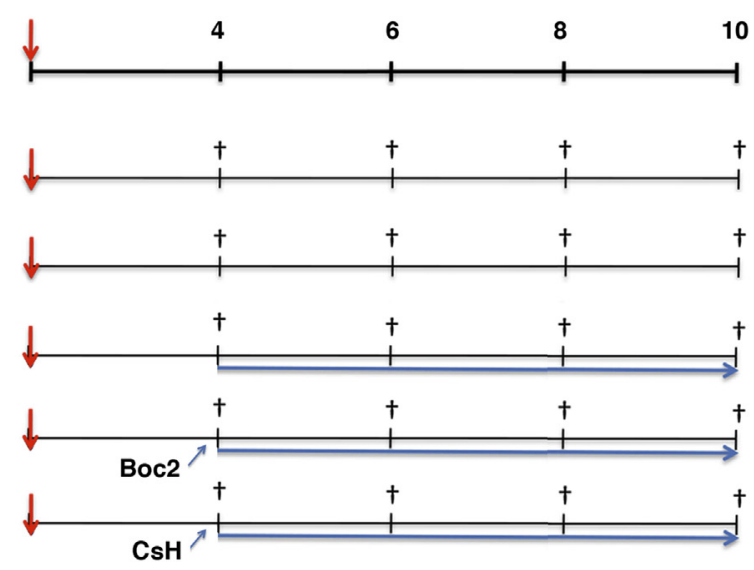

Figure 1 Scheme of the experimental design of the study. The day of the start of the study was defined as day 0 , allowing the association of this time point with the schedule of smoke cessation and compound administration. Red arrows indicate day 0 , the day of the start of the study; blue arrows, time point at which mice received pharmacologic treatment; blue lines, time period in which mice were left to rest at room air after smoking cessation; daggers, time of the sacrifice; mice from groups 3 to 5 were first sacrificed at 4 months plus 8 days after the start of the study. Boc2, N-t-butoxycarbonyl-Phe-DLeu-Phe-DLeuPhe- $\mathrm{OH}$; $\mathrm{CS}$, cigarette smoke; $\mathrm{CsH}$, cyclosporine $\mathrm{H}$; FPR, formyl-peptide receptor; SC, smoke cessation. 
start of the treatment. Another group of mice (group 3) was exposed to CS for 4 months and then left to rest after SC at room air for the next 2, 4, or 6 months.

In addition, two groups of mice were treated at 4 months of CS exposure with the nonselective FPR antagonist Boc2N-tbutoxycarbonyl-Phe-DLeu-Phe-DLeu-Phe-OH (Boc2) (group 4) or with the selective FPR-1 antagonist cyclosporine $\mathrm{H}(\mathrm{CsH})$ (group 5) for the first 3 days after SC and were subsequently sacrificed together with mice of groups 1,2, and 3, at various specified times after SC.

\section{Treatment with FPR Antagonist CsH and Boc2}

After 4 months of CS exposure, a group of mice was treated intraperitoneally twice a day for 3 consecutive days with 10 $\mu \mathrm{g}$ of Boc2 (MP Biomedicals, Santa Ana, CA). As reported in a previous study, inhibitors were dissolved in $50 \mu \mathrm{L}$ of saline containing $7.5 \%$ dimethyl sulfoxide and $2.5 \%$ ethanol. ${ }^{24}$ A second group of mice was treated with $\mathrm{CsH}$ (Enzo Biochem Inc., Farmingdale, NY) $50 \mu \mathrm{g}$ in $50 \mu \mathrm{L}$ of saline containing $7.5 \%$ dimethyl sulfoxide and $2.5 \%$ ethanol, given once a day for 3 consecutive days. After these pharmacologic treatments, mice were sacrificed at various times (8 days, 2 or 6 months) from SC.

\section{Morphology and Morphometry}

Six mice from each group were anesthetized with sodium pentobarbital and sacrificed by severing the abdominal aorta, and the lungs were immediately removed.

Lungs were fixed intratracheally with formalin (5\%) at a pressure of $20 \mathrm{~cm} \mathrm{H}_{2} \mathrm{O}$. Lung volume after fixation was measured by water displacement. Lungs were processed for histologic examination, and lung slides were analyzed for morphology and morphometry. Assessment of emphysema included mean linear intercept (LM) and internal surface area (ISA). ${ }^{27}$ For the determination of the LM and ISA two blinded pathologists (B.B. and E.B.) evaluated 40 histologic fields for each pair of lungs, both vertically and horizontally. The development of goblet cell metaplasia (GCM) was evaluated by periodic acid-Schiff (PAS) reaction. ${ }^{22,32}$ Peribronchiolar fibrosis was quantitated by point counting in paraffinembedded lung after Masson's trichrome staining. ${ }^{12,33}$

\section{Inflammatory Cells Profile in BALF}

The total and differential cell counts in bronchoalveolar lavage fluids (BALFs) were performed in five mice from each group at 4 and 8 months from the start of the study. Before removing lungs, the tracheas were isolated in situ in mice under anesthesia and then cannulated with a 20-gauge blunt needle. With the aid of a peristaltic pump (P-1 pump; Pharmacia Biotech Inc., Piscataway, NJ), the lungs were lavaged in situ three times with $0.6 \mathrm{~mL}$ of saline solution. The average fluid recovery was $>95 \%$.

\section{Immunolocalization of $\mathrm{NF}-\kappa \mathrm{B}$}

Immunohistochemical analysis of NF- $\mathrm{KB}$ was performed on $5-\mu \mathrm{m}$ lung sections. Antigen retrieval was performed by heating in a microwave oven for 20 minutes in $0.01 \mathrm{~mol} / \mathrm{L}$ citrate buffer at $\mathrm{pH} 6.0$ and allowing slow cooling at room temperature. Successively all sections were incubated for 30 minutes in cool solution $0.1 \%$ citrate sodium containing $0.1 \%$ Triton X-100 to facilitate the antibodies accessibility, and then again incubated with $3 \%$ bovine serum albumin for 30 minutes at room temperature to block nonspecific antibody binding. All sections were incubated overnight at $4^{\circ} \mathrm{C}$ with rabbit anti-NF- $\mathrm{BB}$ (dilution 1:200; BioLegend Inc., San Diego, CA). The sections were rinsed with phosphatebuffered saline and incubated with Alexa Fluor488-labelled donkey anti-rabbit antibodies (dilution 1:200; Molecular Probes, Eugene, OR) for 45 minutes in the dark and at room temperature. Finally, the sections were incubated with $1 \mu \mathrm{g} / \mathrm{mL}$ RNase for 30 minutes at room temperature, with $1 \mu \mathrm{g} / \mathrm{mL}$ propidium iodide (Sigma-Aldrich, St. Louis, MO) for an additional 5 minutes and then analyzed with a Zeiss LSM 510 META confocal microscope (Carl Zeiss, Oberkochen, Germany) equipped with krypton/argon and helium/neon lasers. BP-505-530 and LP 560 emission filters were used to acquire fluorescein isothiocyanate and propidium iodide after 488- and 543-nm excitations. Images were captured with the use of a $63 \times$ objective and processed with Zeiss LSM 510 software version 4.2 SP1.

\section{RNA Isolation and cDNA Synthesis}

Total RNA was extracted from lungs of mice by using TRi Reagent (Ambion, Austin, TX) according to the manufacturer's instructions. Five mice for each group were used for RNA isolation. RNA was re-suspended in RT-PCR Grade Water (Ambion), and the amount and purity of RNA were quantified spectrophotometrically by measuring the optical density at 260 and $280 \mathrm{~nm}$. Integrity was checked by agarose gel electrophoresis.

Two micrograms of total RNA was treated with TURBO DNase (TURBO DNA-free kit; Ambion) for 30 minutes and reverse transcribed by using the RETROscript kit (Ambion) according to the manufacturer's instructions. Two hundredths of the final volume of RT was used for real-time RT-PCR.

\section{Real-Time RT-PCR}

Real-time RT-PCR was performed in triplicate for each sample on the MJ Opticon Monitor 2 (MJ Research Co., Waltham, MA) with specific locked nucleic acid probes from the Mouse Universal Probe Library Set (Roche, Indianapolis, IN).

Primers were designed by using the free online ProbeFinder software version 2.53 (Roche Molecular Systems Inc., Branchburg, NJ) that shows a pair of specific primers for 
each probe from the Universal Probe Library set (Roche) (Table 1). The combination of primers and probes provides specific amplification and detection of the target sequence in the sample.

PCR reactions were performed in a volume of $25 \mu \mathrm{L}$ and contained 12.5 $\mu \mathrm{L}$ of FastStart TaqMan Probe Master (Roche), $300 \mathrm{nmol} / \mathrm{L}$ forward and reverse primers (TIBMolbiol, Genova, Italy), $200 \mathrm{nmol} / \mathrm{L}$ Universal Probe Library Set probes, and $5 \mu \mathrm{L}$ of cDNA.

Reactions were incubated at $95^{\circ} \mathrm{C}$ for 10 minutes and then amplified for 40 cycles, each cycle comprised of an incubation step at $94^{\circ} \mathrm{C}$ for 15 seconds, followed by $60^{\circ} \mathrm{C}$ for 1 minute.

The real-time RT-PCR assay included a nontemplate control and a standard curve of four serial dilution points (in steps of 10-fold) of each of the test cDNAs.

The analysis of the results was based on the comparative $\mathrm{Ct}$ method in which $\mathrm{Ct}$ represents the cycle number at which the fluorescent signal, associated with an exponential increase in PCR products, crosses a given threshold. The average of the target gene was normalized to $18 \mathrm{~S}$ rRNA as the endogenous housekeeping gene. ${ }^{34}$

\section{Quantification of GCM}

The total number of cells, as well as the percentage of PASpositive cells, was determined in lung tissue sections from six C57BL/6 mice belonging to each group at 10 months from the start of the experiments and from an additional six smoking mice at 4 months after smoke exposure. The number of cells in airways that demonstrated PAS staining was determined by examining eight intrapulmonary airways per section and counting at least 3000 cells per section. ${ }^{32}$ Data were reported both as the number of positive cells per millimeter of basement membrane and as the percentage of positive cells per total cells.

\section{Statistical Analysis}

Data are presented as means $\pm \mathrm{SD}$. The significance of the differences was calculated using one-way analysis of variance (F-test). A $P$ value $<0.05$ was considered significant.

\section{Results}

\section{Morphologic Response to 4-Month Exposure to CS Is Characterized by Mild Emphysematous Changes}

Histologically, the lungs of the mice exposed to room air for 4 months showed a well-fixed normal parenchyma with normal airways (Figure 2A). After 4 months of smoke exposure mice showed foci of mild emphysema disseminated throughout the lung parenchyma (Figure 2B).

Accordingly, the lungs from mice exposed to CS at this time showed a low but a significant increase of LM value $(+7 \% ; 42.55 \pm 1.2 \mu \mathrm{m}$ versus $39.82 \pm 1.2 \mu \mathrm{m} ; P<0.05)$ (Figure $2 \mathrm{C}$ ) and a significant decrease of ISA value $\left(-10 \% ; 1010 \pm 50 \mathrm{~cm}^{2}\right.$ versus $\left.1129 \pm 35 \mathrm{~cm}^{2} ; P<0.05\right)$ compared with mice belonging to the air-control group (Figure 2D).

Table 1 Primers Sequence and Probe Catalog Number

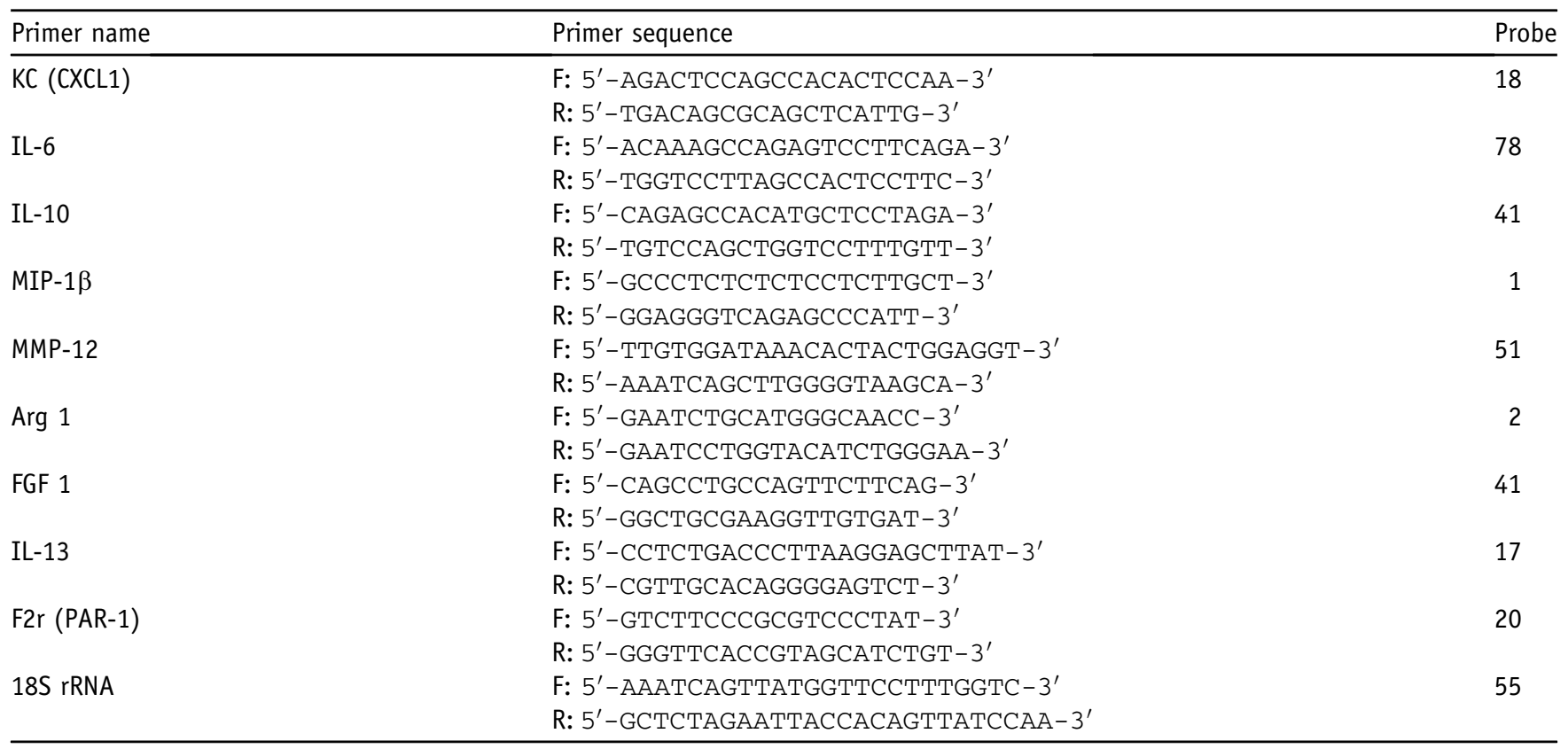

Arg, arginase; F, forward; FGF, fibroblast growth factor; F2r, coagulation factor II receptor; KC, keratinocyte chemoattractant; MIP, macrophage inflammatory protein; MMP, macrophage metalloprotease; PAR, protease-activated receptor; $R$, reverse. 

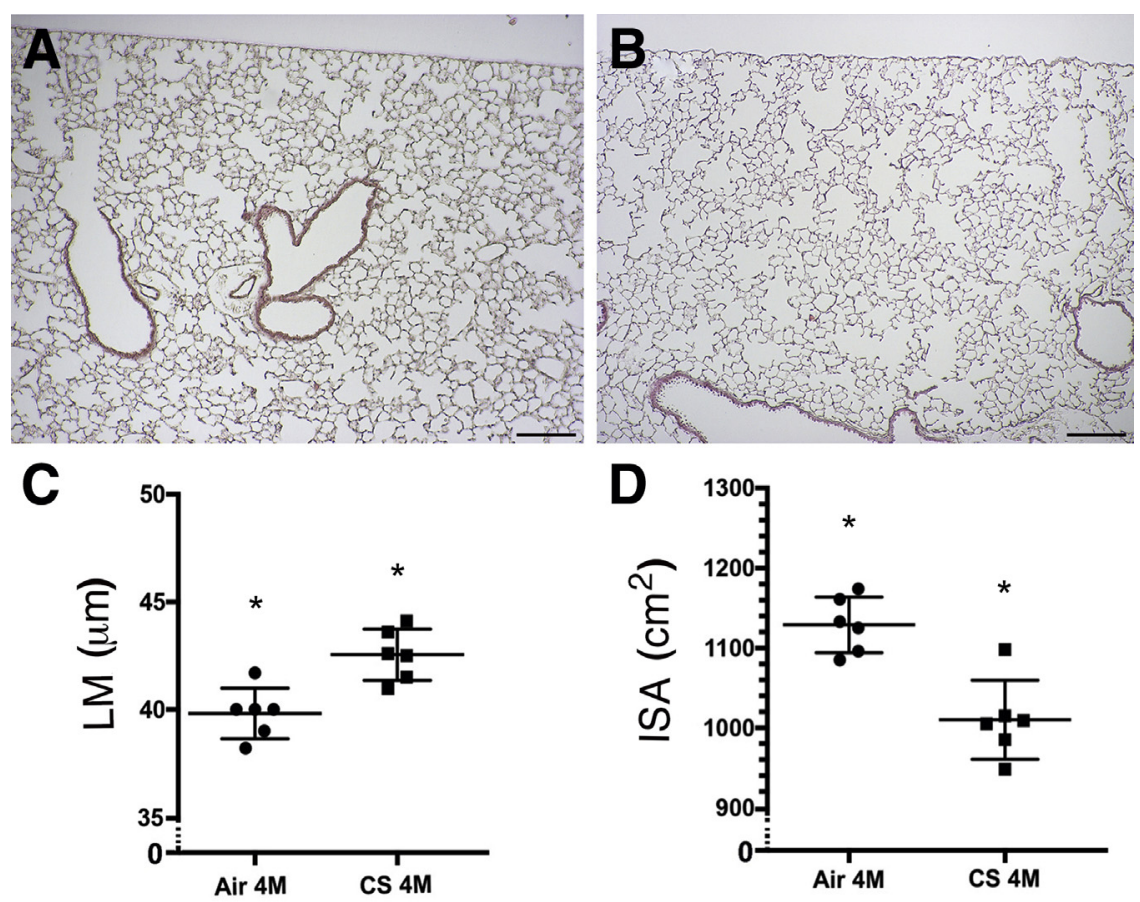

Figure 2 Lung morphology. Histologic examination at 4 months from the start of the study. A and B: Representative histologic sections from lungs of mice at 4 months after air $(\mathbf{A})$ or cigarette smoke (CS) (B) exposure. A: Histologic section of lung from a control mouse at 4 months from the start of the study showing a normal parenchyma. B: A representative histologic section from a mouse at 4 months after CS exposure showing disseminated mild foci of emphysema. Hematoxylin and eosin staining. C and D: Mean linear intercept (LM) values (C) and internal surface areas (ISAs) (D) in lungs of mice exposed for 4 months (CS 4M) or not exposed (Air 4M) to CS. ${ }^{*} P<0.05$ versus air-control mice. Scale bars: 120 $\mu \mathrm{m}(\mathbf{A}$ and $\mathbf{B})$.

\section{Progression of Emphysematous Changes over Time}

No appreciable lung changes were observed in the airexposed control mice at 10 months from the start of the experiment (Figure 3A). However, emphysematous changes in lung parenchyma were evident in mice exposed for 10 months to CS (Figure 3B). The emphysematous lesions were characterized by significant higher LM values $(+14 \%$; $P<0.05)$ and lower ISA values $(-12 \% ; P<0.05)$ than those observed in the group of air-exposed control mice (Figure 3F).

To determine whether SC attenuated inflammation and restored lung changes caused by 4-month exposure to CS, an additional group of mice exposed for 4 months to CS, followed by an additional (4 and) 6-month period without CS exposure (SC group) was studied.

Of interest, the histologic lung sections from the 4-month smoke-exposed mice and allowed to rest for an additional 6 months in room air (Figure 3C) were practically indistinguishable from those of mice exposed for 10 months to CS alone (Figure 3B). These lungs were characterized by evident foci of emphysema disseminated throughout the lung parenchyma. A similar degree of emphysema in mice subjected to SC (SC group) and those exposed to CS for 10 months (CS10 M) was seen as revealed by the morphometric values reported in Figure $3 \mathrm{~F}$ (LM values: $44.57 \pm 1.3$ $\mu \mathrm{m}$ versus $45.78 \pm 2.2 \mu \mathrm{m}$; NS; ISA values: $947 \pm 33 \mathrm{~cm}^{2}$ versus $931 \pm 47 \mathrm{~cm}^{2}$; NS, respectively). Thus, lung emphysema in smoking mice still progressed after SC at a similar extent to that of mice which were continuously exposed to CS for 10 months. Therefore, the cessation of smoking in mice followed by 6 months of rest in the room air, however, resulted in a significant increase in the LM $(+11 \% ; P<0.05)$ and a significant decrease in the ISA $(-10 \% ; P<0.05)$ compared with air-control mice (Air 10 $\mathrm{M})$. The morphometric values reported in Figure $3 \mathrm{~F}$ confirmed that emphysematous changes still progressed after SC during the next period of 6 months and that SC alone had no effect on the progression of lung emphysema once alveolar destruction was initiated.

\section{Lung Inflammation Is Still Present for Long Time in Mice after SC}

At 10 months after chronic smoke exposure, inflammatory cells were increased in lung tissue (Figure 4B) when lung slides were compared with those of mice exposed to room air (Figure 4A). The lung changes observed at 10 months in ex-smoking mice after SC were also associated with a persistent accumulation of inflammatory cells in lung tissue (Figure 4C). The increased lung cellularity observed in these experimental groups was also seen in BALFs of these mice. Mice exposed to CS for 8 months had a significant increase in total, macrophage, and neutrophil cell counts in BALFs compared with air-control mice (Table 2). At the same time point, in mice exposed for 4 months to CS and then left to rest for an additional 4-month period in room air (SC group), macrophage numbers in BALFs decreased almost to control levels. However, neutrophil counts partially decreased at 4 months after SC but failed to reach control values (Table 2). Thus, in mice exposed to CS for 4 months 

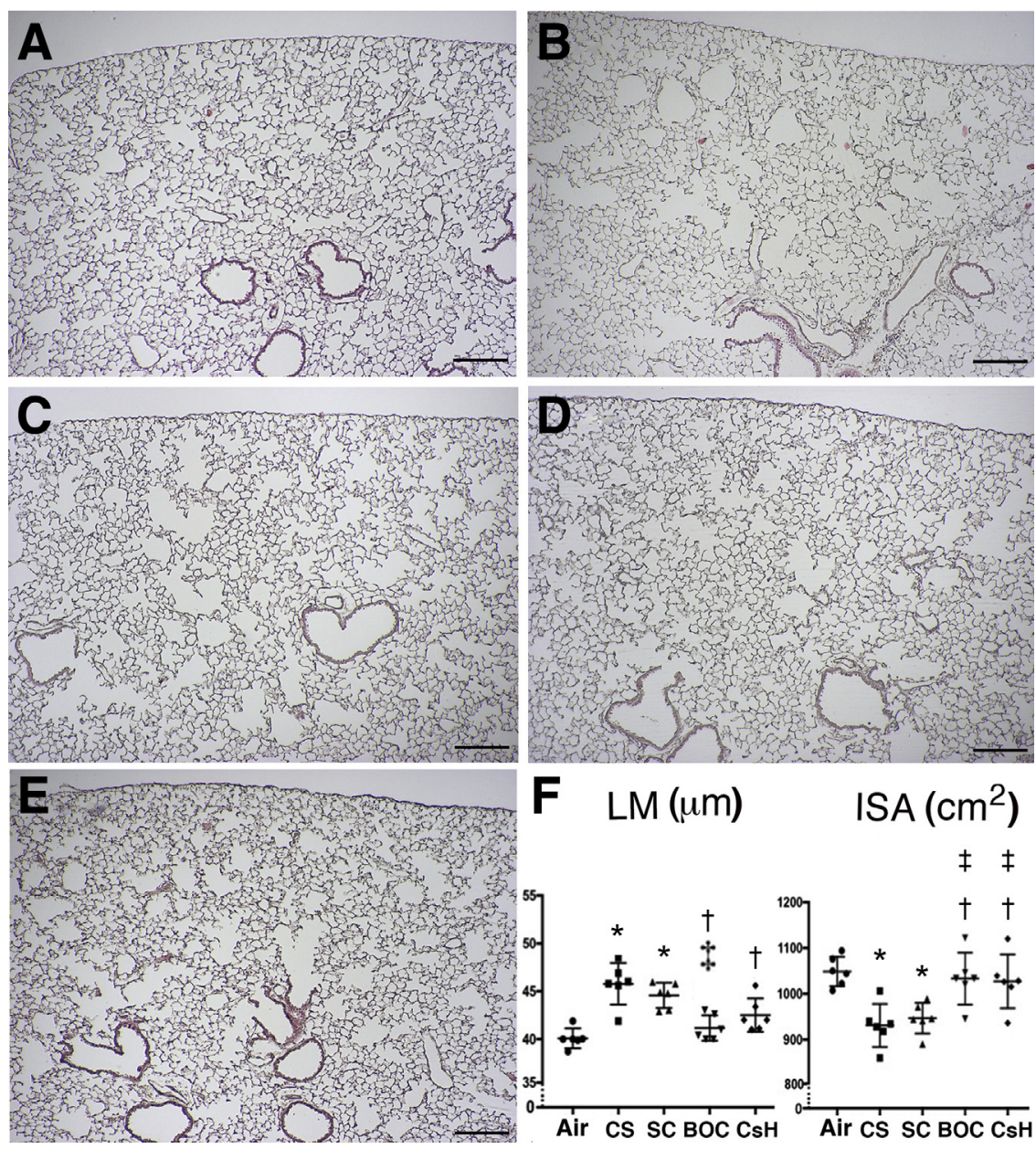

Figure 3 Lung morphology. Histologic examination at 10 months from the start of the study. $\mathbf{A}$ and B: Representative histologic sections from lungs of mice at 10 months after air (A) or cigarette smoke (CS) (B) exposure. C: Lung from a mouse exposed for 4 months to CS and then left to rest after smoking cessation (SC) at room air for 6 months. Evident areas of emphysema were present, scattered throughout the parenchyma. D and E: Representative histologic sections of mice treated with Boc2N-t-butoxycarbonyl-Phe-DLeu-Phe-DLeuPhe- $\mathrm{OH}$ (Boc2) (D) or cyclosporine $\mathrm{H}(\mathrm{CsH} ; \mathrm{E})$, at the time of SC and left to rest at room air for 6 months are shown. Hematoxylin and eosin staining. F: Mean linear intercept (LM) values and internal surface areas (ISAs) in lungs of mice exposed for 10 months to room air (Air), to CS, or exposed for 4 months to CS and left to rest after SC at room air for 6 months. BOC and $\mathrm{CsH}$ indicate mouse groups treated at the time of $\mathrm{SC}$ with Boc2 or $\mathrm{CsH}$, respectively, and left to rest at room air for 6 months. ${ }^{*} P<0.05$ versus air control mice; ${ }^{\dagger} P<0.05$ versus CS-exposed mice; ${ }^{\ddagger} P<0.05$ versus SC group. Scale bars: $120 \mu \mathrm{m}(\mathbf{A}-\mathbf{E})$. BOC, $\mathrm{N}$-Tert-Butyloxycarbonyl-Phe-Leu-Phe-Leu-Phe. a significant increase of neutrophil number was still evident after 4 months from SC.

These results indicated that SC in mice was followed by a persistent inflammatory lung response that was associated with the progression of emphysematous lesion.

\section{Chronic Lung Inflammation Is Characterized by Persistent NF- $\kappa$ B Activation}

$\mathrm{NF}-\kappa \mathrm{B}$ was a major regulator of innate immunity and its activation resulted in fairly rapid changes in gene expression. In the normal condition, this factor, in its inactive status, can be localized in the cytoplasm of many lung cells by using a rabbit antibody recognizing the p65 (RelA) component of the NF- $\kappa \mathrm{B}$ complex (Figure 5A). When activated, RelA trans-located to the nucleus where it promoted expression of proinflammatory molecules.

A positive and persistent reaction for p65/RelA was still observed at 6 months from the start of experiments in the nuclei of several lung macrophages and epithelial cells of smoking mice (Figure 5B) as well as of ex-smoker mice after SC (Figure 5C). The persistent nuclear positive reaction for RelA was accompanied by a significant up-regulation of mRNA of proinflammatory cytokines such as IL-6, macrophage inflammatory protein (MIP)-1, keratinocyte chemoattractant (KC), and anti-inflammatory IL-10 (Figure 5F).

\section{FPR Antagonists Reduce Lung Inflammation and Prevent the Progression of the Lung Changes after SC}

To stop the vicious cycle that was hypothesized to be the cause of persistent pulmonary inflammation after SC, Boc2 and $\mathrm{CsH}$, two antagonists of FPR-1 and FPR-2, were administered in mice on the first 3 days after 4 months of CS exposure. These mice were allowed to rest at room air for the next 6 months.

At day 8 after the start of Boc2 or $\mathrm{CsH}$ treatment, total and differential cell counts were performed in BALFs of five mice for each experimental groups. The results are reported in Table 3.

In the group of mice treated with Boc2 or $\mathrm{CsH}$, cell counts showed a significant decrease of total cell population compared with ex-smoker mice exposed to CS for 4 months and then allowed to rest for the next 8 days. Of interest, both antagonists led to a significant reduction of neutrophil 


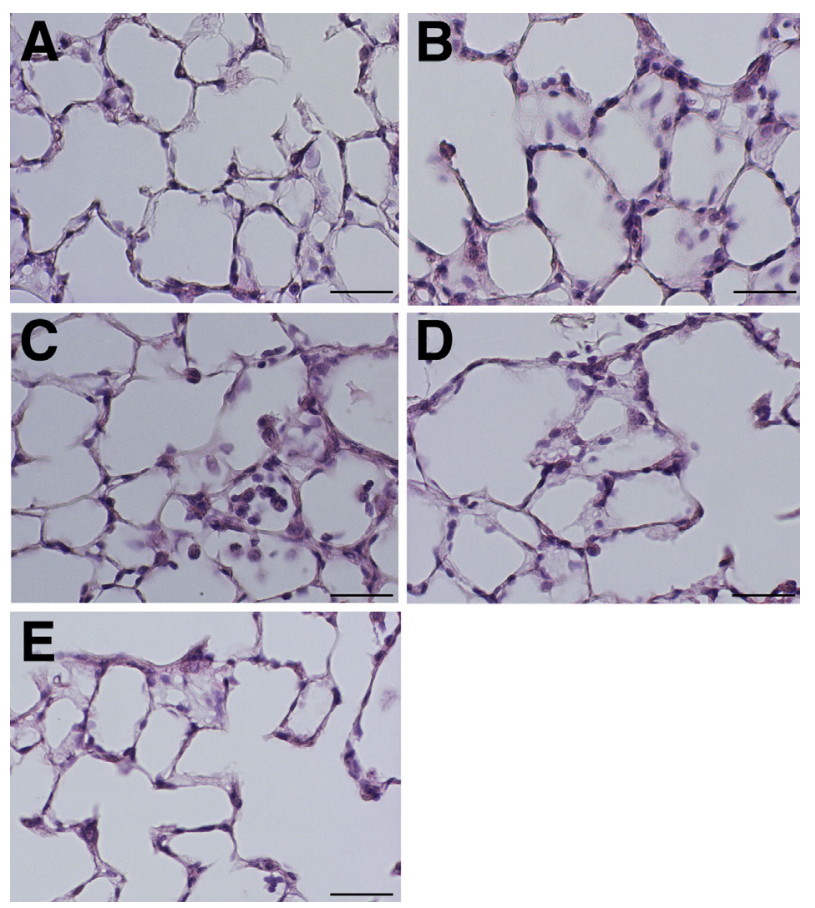

Figure 4 Inflammatory cells in lung tissues at 10 months and in bronchoalveolar lavage fluids (BALFs) at 8 months from the start of the study. A: Representative histologic sections from lungs of mice at 10 months after air exposure in which inflammatory cells were virtually absent. B: At 10 months after chronic smoke exposure inflammatory cells were present throughout lung parenchyma. C: The lungs of ex-smoking mice after SC mice observed at 10 months were also characterized by a persistent accumulation of inflammatory cells in lung tissue. D and E: Few inflammatory cells were present in lung parenchyma of mice receiving a treatment with Boc2N-t-butoxycarbonyl-Phe-DLeu-Phe-DLeu-Phe-OH (Boc2) (D) or cyclosporine $\mathrm{H}(\mathrm{CsH})$ (E). Hematoxylin and eosin staining. Scale bars: $40 \mu \mathrm{m}(\mathbf{A}-\mathbf{E})$.

migration in BALFs compared with mice exposed to CS for 4 months, which did not receive any pharmacologic treatment (Table 3). However, a mild increase of neutrophils and lymphocytes was present in mice treated with Boc2 compared with air-control mice. Therefore, $\mathrm{CsH}$ or Boc2

Table 2 Total and Differential Cell Count in BALFs after 8 Months from the Start of the Study

\begin{tabular}{llll}
\hline BALF cells & Air-exposed & Smoke-exposed & Smoke cessation \\
\hline $\begin{array}{l}\text { Total cell } \\
\text { count, } \times 10^{5}\end{array}$ & $1.35 \pm 0.4$ & $1.96 \pm 0.43^{*}$ & $1.50 \pm 0.14$ \\
$\begin{array}{c}\text { Differential cell } \\
\quad \text { count, } \times 10^{5}\end{array}$ & & \\
$\begin{array}{c}\text { Macrophages } \\
\text { Neutrophils }\end{array}$ & $0.13 \pm 0.3$ & $1.36 \pm 0.35$ & $1.11 \pm 0.11$ \\
Lymphocytes & $0.08 \pm 0.04$ & $0.46 \pm 0.11^{*}$ & $0.30 \pm 0.04^{* \dagger}$ \\
\hline
\end{tabular}

Data are expressed as means \pm SD from 5 mice per group. They represent data from mice exposed for 8months to air, cigarette smoke, or mice left to rest for 4 months to room air after smoke cessation. The slides were stained with Diff Quick.

${ }^{*} P<0.05$ versus air exposure.

${ }^{\dagger} P<0.05$ versus smoke exposure.

BALF, bronchoalveolar lavage fluid. treatment after SC was effective in reducing the migration of neutrophils in BALFs.

The reduction of neutrophilic inflammation with FPR antagonists after SC strongly suggested an important role of FPR signaling in modulating the inflammatory response once lung destruction was already present.

In addition, the histologic evaluation of lungs of smoking mice receiving Boc2 or $\mathrm{CsH}$ treatment revealed at 6 months after SC a mild deterioration of lung changes (Figure 3, D and E) compared with mice that did not receive any pharmacologic treatment during the first days after SC (Figure 3C). The morphologic and morphometric assessment of lung changes performed at 6 months after SC confirmed that the attenuation of inflammatory response obtained by the treatment with FPR antagonists favored a mild evolution of lung lesions preventing the deterioration of pulmonary structures which usually follows SC (Figure 3F). Of interest, only a few inflammatory cells were present in lung parenchyma of mice receiving a treatment with Boc2 (Figure 4D) or CsH (Figure 4E). These features were preceded by i) marked and significant reduction of neutrophils in BALFs of mice receiving FPR antagonists after SC (Table 3), ii) absence of nuclear reaction for NF-кB (Figure 5, D and $\mathrm{E}$ ), and iii) no significant changes in mRNA expression of proinflammatory cytokines such as MIP-1, KC, and IL-6 (Figure 5F).

Of interest, like in SC group, mice receiving FPR antagonists showed an up-regulation of mRNA for the antiinflammatory cytokine IL-10 (Figure 5F).

The reduction of neutrophilic inflammation with the administration of FPR antagonists after SC strongly suggested an important role of FPR signaling in modulating and perpetuating the inflammatory response once lung destruction was already present.

\section{Treatment with FPR Antagonists Prevents Peribronchiolar Fibrosis and Reduces the Number of Goblet Cells in Airway Epithelium}

Only a small amount of collagen was found around bronchioles and distal bronchi of air-control mice at 10 months from the start of the experiments (Figure 6A). At the same time point, peribronchiolar regions of lungs from smoking mice as well as from ex-smoker mice after SC showed an increased collagen deposition (Figure 6, B and D). The quantification of collagen deposition areas by point counting did not reveal differences, at 10 months from the start of the study, between smoking mice and mice that stopped smoking after 4 months of CS exposure (Figure 7A). However, an increased deposition of collagen was observed in the latter group of mice (Figure 6D) compared with that observed at 4 months of CS exposure (Figure 6C). On the contrary, minimal differences in morphology and collagen deposition area quantitation were observed among aircontrol mice (Figure 6A) and mice receiving Boc2 (Figure 6E) or $\mathrm{CsH}$ (Figure 6F). The point counting analysis 

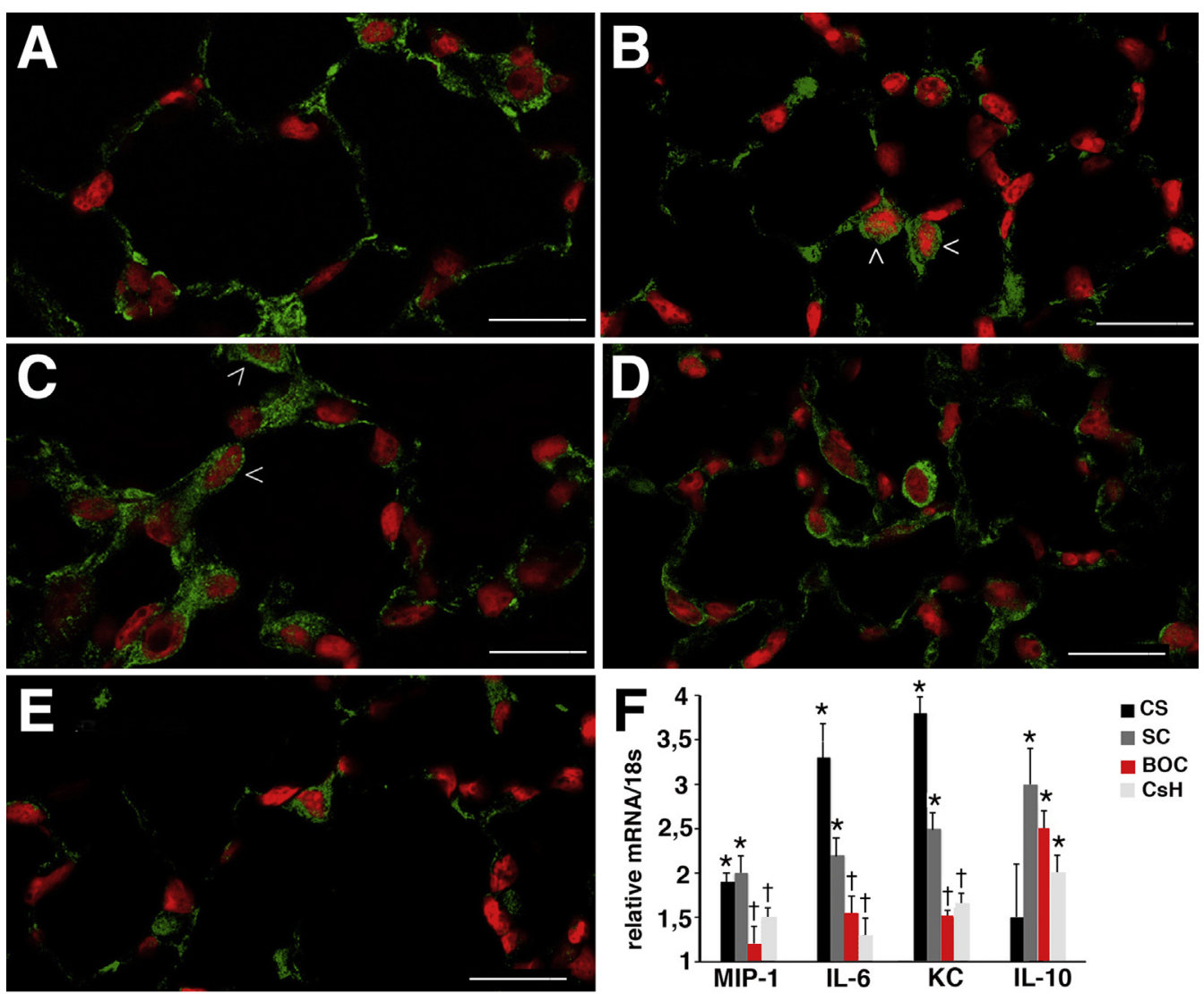

Figure 5 Nuclear translocation of NF- $\kappa B$ and real-time PCR analysis of mRNAs for some NF- $\kappa B$ target genes encoding for proinflammatory or anti-inflammatory cytokines and chemokines. A: Immunohistochemical reaction (green staining) for NF- $\kappa B$ in lung section from air-control mouse. In this group of mice, NF- $\kappa B$ in its inactive status was localized in the cytoplasm of macrophages and alveolar cells. B: Lung section from a mouse exposed for 6 months to cigarette smoke (CS). NF- $\kappa B$ could be observed in the nuclei of several macrophages and alveolar cells (arrowheads). C: Nuclear localization of NF- $\kappa B$ (green staining) could be appreciated also in lung slides from mice exposed for 4 months to CS and then left to rest after smoking cessation (SC) at room air for 2 months (arrowheads). D and E: No nuclear localization of NF-KB could be seen in lung histologic sections of mice treated with Boc2N-t-butoxycarbonyl-Phe-DLeu-Phe-DLeu-Phe-OH (BOC) (D) or cyclosporine $\mathrm{H}(\mathrm{CsH} ; \mathrm{E})$, at the time of smoking cessation and left to rest at room air for 2 months. F: Real-time PCR analysis of mRNAs for chemokine (C-C motif) ligand/ macrophage inflammatory protein-1 $\beta$ (MIP-1 $\beta)$, IL-6, cytokine-induced neutrophil-attracting chemokine [Cxcl1/keratinocyte chemoattractant (KC)], and IL-10 performed on lungs from mice for each experimental group at 6 months from the start of experiments. Values are corrected for 18S rRNA and normalized to a median control value of 1.0. Data are expressed as means \pm SD. $n=5$ mice for each experimental group $(\mathbf{F}) .{ }^{*} P<0.05$ versus air-control values; ${ }^{\dagger} P<0.05$ versus $\mathrm{SC}$ group. Scale bars: $20 \mu \mathrm{m}(\mathbf{A}-\mathbf{E})$.

performed on collagen deposition areas substantiated these observations (Figure 7A). In addition, at 8 months from the start of the study, a significant increase of mRNA expression for arginase-1 (Argl) and fibroblast growth factor-1 (Fgfl) was seen in lung samples of smoking as well as ex-smoker mice of the SC groups (Figure 7B). All these gene products were involved in fibrotic reactions.

GCM in response to smoke treatment was assessed by counting PAS-positive cells in mice at 10 months from the start of the experiments. Data were reported both as the

Table 3 Total and Differential Cell Count in BALFs at 4 Months and 8 Days after the Start of the Study

\begin{tabular}{llllll}
\hline BALF cells & Air & Smoke & Smoke cessation & Smoke cessation + Boc2 & Smoke cessation + CsH \\
\hline $\begin{array}{l}\text { Total cell count, } \times 10^{5} \\
\text { Differential cell count, } \times 10^{5}\end{array}$ & $0.96 \pm 0.16$ & $1.6 \pm 0.19^{*}$ & $1.49 \pm 0.21^{*}$ & $1.15 \pm 0.08^{*^{\dagger}}$ & $1.10 \pm 0.25^{\dagger}$ \\
$\quad$ & & & & \\
Macrophages & $0.82 \pm 0.15$ & $1.13 \pm 0.16^{*}$ & $1.07 \pm 0.14^{*}$ & $0.95 \pm 0.09$ & $0.92 \pm 0.22$ \\
$\quad$ Neutrophils & $0.08 \pm 0.02$ & $0.34 \pm 0.04^{*}$ & $0.29 \pm 0.05^{*}$ & $0.12 \pm 0.01^{* \dagger}$ & $0.10 \pm 0.03^{\dagger}$ \\
$\quad$ Lymphocytes & $0.06 \pm 0.01$ & $0.13 \pm 0.01^{*}$ & $0.14 \pm 0.03^{*}$ & $0.08 \pm 0.02^{* \dagger}$ & $0.08 \pm 0.02^{* \dagger}$ \\
\hline
\end{tabular}

Data are expressed as means \pm SD from 5 mice per group. They represent data from animals exposed to air, cigarette smoke, or exposed to cigarette smoke for 4 months and left to rest for 8 days in room air after smoke cessation. The last groups of mice received formyl-peptide receptor antagonists after smoking cessation. The slides were stained with Diff Quick.

${ }^{*} P<0.05$ versus air exposure.

${ }^{\dagger} P<0.05$ versus smoke exposure.

BALF, bronchoalveolar lavage fluid; Boc2, N-t-butoxycarbonyl-Phe-DLeu-Phe-DLeu-Phe-OH; CsH, cyclosporine $\mathrm{H}$. 


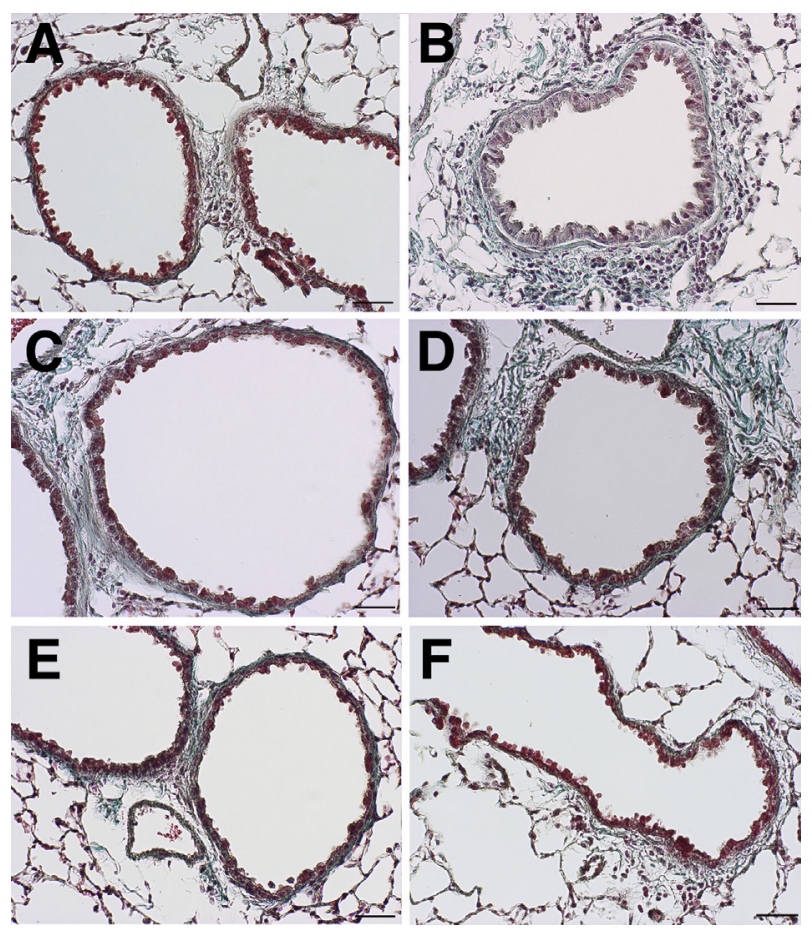

Figure 6 Lung morphology. Airway morphology: peribronchiolar fibrosis. Histologic sections from distal airways after Masson's trichrome staining. A: Distal airway of an air-exposed mouse showing a normal appearance. B: Peribronchiolar region of a mouse at 10 months after cigarette smoke (CS) exposure thickened by an evident fibrotic reaction. Note a large number of inflammatory cells in the peribronchiolar area. C: Tissue section of a smoking mouse at 4 months of exposure showing a mild increase of collagen (seagreen stain) around a distal airway. Inflammatory cells were present in the surrounding areas. D: Collagen was markedly increased in the peribronchiolar spaces of mice exposed for 4 months to CS and then left to rest after smoking cessation at room air for 6 months. Inflammatory cells were still present in the peribronchiolar spaces. $\mathbf{E}$ and F: Peribronchiolar spaces of mice at 6 months after smoking cessation that received Boc2N-t-butoxycarbonyl-PheDLeu-Phe-DLeu-Phe-OH (Boc2; E) or cyclosporine $\mathrm{H}(\mathrm{CsH} ; \mathbf{F})$ at 4 months of CS exposure. C: Minimal differences in sea-green-stained areas are observed between the latter groups of mice and those sacrificed at 4 months of smoke exposure. Masson's trichrome stain. Scale bars: $40 \mu \mathrm{m}(\mathbf{A}-\mathbf{F})$.

number of positive cells per millimeter of basement membrane (Figure 7C) and as the percentage of positive cells per total cells (Figure 7D). As recognized, control mice practically did not have goblet cells in their bronchi and bronchioles, ${ }^{9}$ and also at this time PAS staining was absent in the airway epithelium of air-exposed control mice (Figure 7E). Quantitation of PAS-positive cells revealed that approximately $10 \%$ of all airway cells in mice smoking for 10 months are goblet cells (Figure 7, D and F) and that the extent of GCM measured as the percentage of PAS-positive cells was quite similar for mice exposed for a period of 4 months to CS (Figure 7G) and those exposed for 4 months to $\mathrm{CS}$ and then left to rest for an additional 6-month period in room air (SC group) (Figure 7, D and $\mathrm{H}$ ). In mice exposed to $\mathrm{CS}$, treated with $\mathrm{BOC}$ or $\mathrm{CsH}$, and left to rest in room air for the next 6 months, a marked significant reduction of PAS-positive cells was observed (Figure 7, I and $\mathrm{J}$ ) with a low significant percentage of PAS-positive cells in respect to other smoking groups that did not receive pharmacologic treatments (Figure 7D). The numbers of PAS-positive cells per millimeter of basement membrane in each experimental group is reported in Figure 7C. The development of GCM was preceded by a significant upregulation of mRNA for $I l 13$ and protease-activated receptor-1 (Par1) coded by F2 $r$ gene (Figure 7B). Both factors are implicated in this adaptive tissue differentiation.

\section{Discussion}

Several studies in humans and animal experiments have demonstrated that, once COPD is initiated, the pulmonary inflammatory response continues ${ }^{5-7}$ and that the enlarged alveolar airspace cannot be reversed after SC. Available therapies do not adequately suppress inflammation and are not able to stop the vicious cycle that is at the basis of persistent inflammation.

In this study it was demonstrated that also in mice chronically exposed to CS, lung inflammation persists after $\mathrm{SC}$ and is associated with a progressive alveolar loss and remodeling of respiratory tract, characterized by the onset of bronchial and bronchiolar GCM and peribronchiolar fibrosis. Persistent inflammation is characterized in these mice by an increased cellularity with a significant increase of neutrophils and macrophages in the peripheral structure of the lung and a persistent activation of NF- $\mathrm{KB}$ associated with a nuclear localization of the p65 (RelA) component of the complex that modulates transcription of target genes. In particular, RelA can enhance the transcription of a series of downstream target genes ${ }^{35}$ such as proinflammatory or antiinflammatory cytokines and chemokines (ie, KC, MIP-1 $\beta$, IL-6, and IL-10) or enzymes (such as macrophage metalloprotease-12, arginase 1) and factors (ie, FGF-1, PAR-1, and IL-13), which have been implicated in alveolar destruction or in peribronchiolar and bronchial remodeling.

In particular, up-regulation of genes encoding the attractants CXCL1/KC (the murine IL- 8 homolog) ${ }^{36}$ and chemokine (C-C motif) ligand 4/MIP-1 $\beta^{37}$ would explain the prolonged presence of polymorphonuclear leukocytes and macrophages in peripheral lung structures of mice after SC, whereas the increased expression of arginase 1 and FGF$1^{38,39}$ could explain the consistent collagen deposition in peribronchiolar areas. In addition, the strong macrophage metalloprotease-12 expression coincided with the progression phase of the disease probably for enzyme destruction of alveolar structures by macrophages. ${ }^{40} \mathrm{~A}$ link between PAR1 and IL-13 overexpression and development of GCM may be postulated on the basis of our recent work and other ones published on this matter. ${ }^{32,41}$

Of importance, the modulation of FPR-related signaling in mice by using FPR inhibitors halts chronic inflammation and prevents the deterioration of pulmonary structures that follow SC. 
A

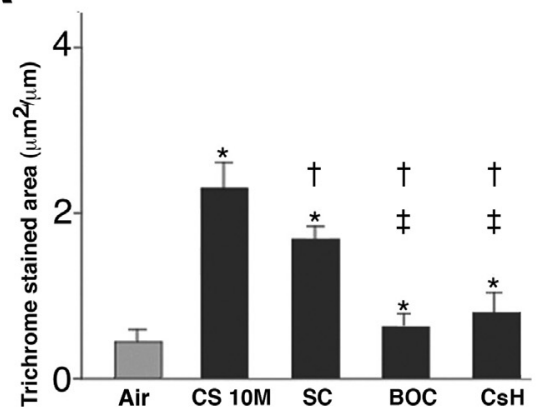

C

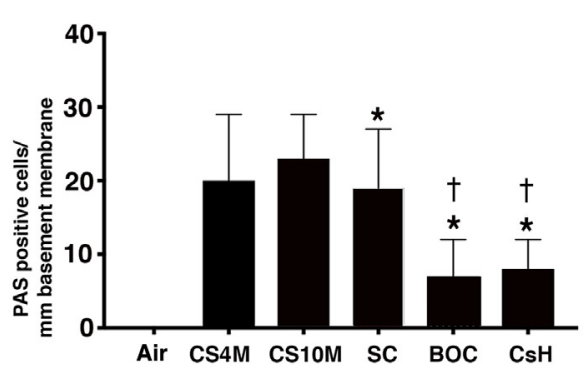

D

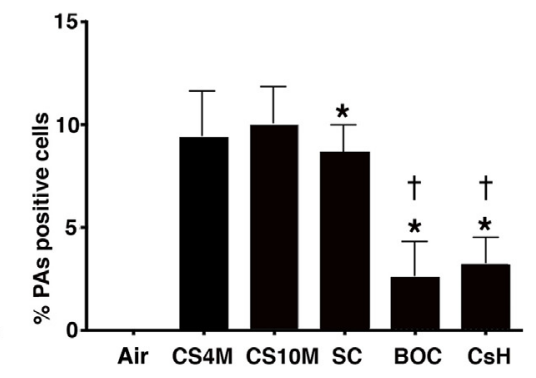

B

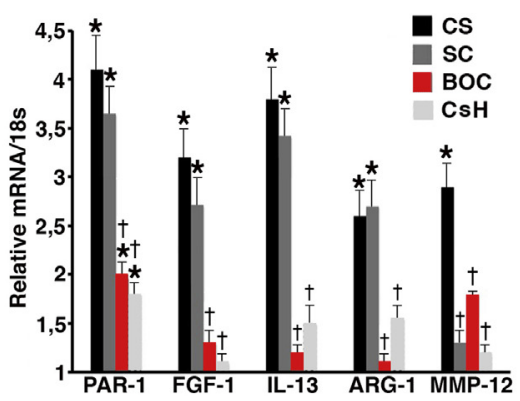

Figure 7 Masson's trichrome-stained areas, real-time PCR analysis of mRNAs for some NF- $\kappa B$ target genes, quantification of goblet cell metaplasia in lungs of mice from various experimental groups at 10 months from the start of the study. A: Data are reported as values of sea green area per micrometer length of basement membrane of bronchioles 150 to $300 \mathrm{~mm}$ of internal diameter at 10 months from the start of the study. ${ }^{\star} P<0.05$ versus air exposed mice; ${ }^{\dagger} P<0.05$ versus CSexposed mice; ${ }^{\ddagger} P<0.05$ versus $\mathrm{SC}$ group. B: Real-time $P C R$ analysis of mRNAs for proteaseactivated receptor-1 (PAR-1, F2r), fibroblast growth factor-1 (Fgf1), IL-13 (Il13), arginase-1 (Arg1), and macrophage metalloprotease-12 (Mmp12) performed on lungs from mice at 8 months from the start of experiments. Values are corrected for $18 \mathrm{~S}$ rRNA and normalized to a median control value of 1.0. Data are presented as mean \pm SD. ${ }^{*} P<0.05$ versus air-control values; ${ }^{\dagger} P<0.05$ versus SC group. C: Number of periodic acid-Schiff (PAS)-positive cells per millimeter of basement membrane. D: Percentage of PAS-positive cells per total cells. At 6 months after smoking cessation (SC) mice which received Boc2N-tbutoxycarbonyl-Phe-DLeu-Phe-DLeu-Phe- $\mathrm{OH}$ (Boc2 or $\mathrm{BOC}$ ) or cyclosporine $\mathrm{H}(\mathrm{CsH})$ at 4 months of cigarette smoke (CS) exposure (CS4M) showed a marked significant reduction of PAS-positive cells in airway epithelium. ${ }^{*} P<0.05$ versus CS group at 10 months; ${ }^{\dagger} P<0.05$ versus SC group. E: Lung from air-control mouse, no PAS-positive cells were present in tissue sections. F: Lung from CS-exposed mouse at 10 months (CS10M) showing a large number of goblet cells in the epithelium of bronchioles and in middle-sized bronchi. G: Goblet cell metaplasia could be appreciated in airway epithelium of CS-exposed mice also at 4 months from the start of the study. H: Significant areas of goblet cell metaplasia could be appreciated in airway epithelium of ex-smoker mice at 6 months from SC. I and J: At 6 months after SC mice which received Boc2 (I) or CsH (J) at 4 months of CS exposure showed only few scattered goblet cells in the epithelium of bronchioles and middle-sized bronchi (arrowheads). PAS stain. Data are expressed as means \pm SD. $n=6$ mice in all groups $(\mathbf{A}) ; n=5$ mice for each experimental group (B). Scale bars $=100 \mu \mathrm{m}(\mathbf{E}-\mathbf{J})$.
FPRs belong to the family of pattern recognition receptors, G-protein-coupled receptor family that regulate innate immune responses. ${ }^{42}$ Three FPRs have been identified in humans: FPR-1, FPR-2, and FPR-3, which have been described across several species, including mouse. Distinct to the other member of the FPR family, the function of FPR-3 remains relatively poorly understood. FPR-1 and FPR-2 have diverse roles in the initiation, propagation, and resolution of inflammation. ${ }^{43}$ Murine orthologs of human FPR-1 and FPR-2 share a relative high sequence homology, are expressed on similar cell types (neutrophils, macrophages, monocytes, fibroblasts, epithelial, and endothelial cells), and induce the same effects of neutrophil chemotaxis, degranulation, reactive oxygen species production, and phagocytosis. ${ }^{44}$ FPR-1 was originally identified in phagocytic leukocytes and mediates cell chemotaxis and activation in response to the bacterial formylated chemotactic peptides (eg, formyl-methionyl-leucyl phenylalanine). Agonist binding to FPR-1 elicits a signal transduction cascade involving phosphatidylinositol 3-kinase, protein kinase $\mathrm{C}$, mitogen-activated protein kinases, and the transcription factor NF- $\mathrm{KB}^{45}$ Unlike FPR-1 that is expressed at high levels in both peripheral blood monocytes and neutrophils, FPR-2 is prevalently expressed in monocytes. $^{45}$ Signals on both receptors can induce neutrophil recruitment to sites of inflammation, reactive oxygen 
species production, degranulation, and cytokine release ${ }^{42}$ as well as FPR signaling can induce an alternatively activated phenotype in macrophages that express IL-13, IL-4, and arginase that uses arginine to produce proline, an essential amino acid for collagen synthesis. Although FPRs were initially thought to bind only $\mathrm{N}$-formylated peptides of bacterial origin (which are recognized as potent pathogenassociated molecular patterns), FPRs also bind mitochondrial formylated peptides (damage-associated molecular patters) ${ }^{46}$ released from the cell after necrotic cell death, and other inflammatory nonformylated ligands that include cathepsin $\mathrm{G}$, serum amyloid $\mathrm{A}$, and $\beta$ amyloid or antiinflammatory agonist such as annexin A1 and lipoxin A4. ${ }^{42}$

Studies have indicated that formylated peptides, FPRs, and in particular FPR-1 may be principal conductors in inflammatory processes in sterile- ${ }^{24,26}$ and infection-related ${ }^{47}$ diseases. FPR-1 and formylated peptides, which are active components of $\mathrm{CS},{ }^{48}$ have been involved in smokinginduced lung damage, and studies performed in our laboratory demonstrated that $\mathrm{Fprl}^{-1-}$ mice are protected from CS-induced emphysematous changes, ${ }^{24}$ suggesting that formylated peptides within CS are central to disease pathogenesis. A similar beneficial reduction in inflammatory response, with fewer migrating neutrophils and macrophages and lower proinflammatory cytokine levels, was observed after acute or subacute exposure to CS. ${ }^{24}$ Further support for the role of FPRs in COPD pathogenesis has come from additional experimental studies in which alterations resembling COPD are induced in mice by a single intratracheal instillation of formylated peptides. ${ }^{32,49}$

Actually, these receptors are overexpressed in patients with COPD, ${ }^{25}$ and, in established COPD, FPR activation by formyl-peptides released from mitochondria of necrotic cells or bacteria (that usually colonize pulmonary structures) may promote persistent inflammation by feeding the vicious cycle that causes persistent inflammation after SC.

In the present study, it was demonstrate that selective inhibitors of FPR and FPR-1 exert therapeutic efficacy in an experimental animal model of COPD by halting the disease progression after SC. The inhibitor blockade of FPR-1 and FPR-1/FPR-2-related signaling can mitigate, after SC, the persistent inflammation and prevents the deterioration of pulmonary structures, which lead to airspace enlargement and airway remodeling.

The present study is the first to demonstrate a role for FPRs in persistent inflammation and in progressive lung destruction and maladaptive airway remodeling that follows $\mathrm{SC}$ in mice.

It also provides a compelling rationale for FPR inhibition as a novel therapeutic strategy for treating COPD patients after SC.

\section{References}

1. Fabbri LM, Rabe KF: From COPD to chronic systemic inflammatory syndrome? Lancet 2007, 370:797-799
2. Mannino DM, Watt G, Hole D, Gillis C, Hart C, McConnachie A, Davey Smith G, Upton M, Hawthorne V, Sin DD, Man SF, Van Eeden S, Mapel DW, Vestbo J: The natural history of chronic obstructive pulmonary disease. Eur Respir J 2006, 27:627-643

3. Scanlon PD, Connett JE, Waller LA, Altose MD, Bailey WC, Buist AS, Tashkin DP; Lung Health Study Research Group: Smoking cessation and lung function in mild-to-moderate chronic obstructive pulmonary disease. Am J Respir Crit Care Med 2000, 161:381-390

4. Simmons MS, Connett JE, Nides MA, Lindgren PG, Kleerup EC, Murray RP, Bjornson WM, Tashkin DP: Smoking reduction and the rate of decline in FEV(1): results from the Lung Health Study. Eur Respir J 2005, 25:1011-1017

5. Willemse BW, ten Hacken NH, Rutgers B, Lesman-Leegte IG, Postma DS, Timens W: Effect of 1-year smoking cessation on airway inflammation in COPD and asymptomatic smokers. Eur Respir J 2005, $26: 835-845$

6. Gamble E, Grootendorst DC, Hattotuwa K, O'Shaughnessy T, Ram FS, Qiu Y, Zhu J, Vignola AM, Kroegel C, Morell F, Pavord ID, Rabe KF, Jeffery PK, Barnes NC: Airway mucosal inflammation in COPD is similar in smokers and ex-smokers: a pooled analysis. Eur Respir J 2007, 30:467-471

7. Lapperre TS, Postma DS, Gosman MM, Snoeck-Stroband JB, ten Hacken NH, Hiemstra PS, Timens W, Sterk PJ, Mauad T: Relation between duration of smoking cessation and bronchial inflammation in COPD. Thorax 2006, 61:115-121

8. Braber S, Henricks PA, Nijkamp FP, Kraneveld AD, Folkerts G: Inflammatory changes in the airways of mice caused by cigarette smoke exposure are only partially reversed after smoking cessation. Respir Res 2010, 11:99

9. Martorana PA, Cavarra E, Lucattelli M, Lungarella G: Models for COPD involving cigarette smoke. Drug Discov Today Dis Models 2006, 3:225-230

10. Rahman I, De Cunto G, Sundar IK, Lungarella G: Vulnerability and genetic susceptibility to cigarette smoke-induced emphysema in mice. Am J Respir Cell Mol Biol 2017, 57:270-271

11. Tuder RM, Petrache I: Pathogenesis of chronic obstructive pulmonary disease. J Clin Invest 2012, 122:2749-2755

12. De Cunto G, Lunghi B, Bartalesi B, Cavarra E, Fineschi S, Ulivieri C, Lungarella G, Lucattelli M: Severe reduction in number and function of peripheral $\mathrm{T}$ cells does not afford protection toward emphysema and bronchial remodeling induced in mice by cigarette smoke. Am J Pathol 2016, 186:1814-1824

13. Churg A, Cosio M, Wright JL: Mechanisms of cigarette smokeinduced COPD: insights from animal models. Am J Physiol Lung Cell Mol Physiol 2008, 294:L612-L631

14. Lucattelli M, Bartalesi B, Cavarra E, Fineschi S, Lunghi B, Martorana PA, Lungarella G: Is neutrophil elastase the missing link between emphysema and fibrosis? Evidence from two mouse models. Respir Res 2005, 6:83

15. Rahman I, Adcock IM: Oxidative stress and redox regulation of lung inflammation in COPD. Eur Respir J 2006, 28:219-242

16. MacNee W, Rahman I: Oxidants and antioxidants as therapeutic targets in chronic obstructive pulmonary disease. Am J Respir Crit Care Med 1999, 160:S58-S65

17. Rossi R, Giustarini D, Fineschi S, De Cunto G, Lungarella G, Cavarra E: Differential thiol status in blood of different mouse strains exposed to cigarette smoke. Free Radic Res 2009, 43:538-545

18. Curtis JL, Freeman CM, Huffnagle GB: "B" for bad, beneficial, or both? Lung lymphoid neogenesis in chronic obstructive pulmonary disease. Am J Respir Crit Care Med 2015, 192:648-651

19. Calverley PM, Anderson JA, Celli B, Ferguson GT, Jenkins C, Jones PW, Yates JC, Vestbo J; TORCH investigators: Salmeterol and fluticasone propionate and survival in chronic obstructive pulmonary disease. N Engl J Med 2007, 356:775-789

20. Hatzelmann A, Morcillo EJ, Lungarella G, Adnot S, Sanjar S, Beume R, Schudt C, Tenor H: The preclinical pharmacology of 
roflumilast-a selective, oralphosphodiesterase 4 inhibitor in development for chronic obstructive pulmonary disease. Pulm Pharmacol Ther 2010, 23:235-256

21. Churg A, Tai H, Coulthard T, Wang R, Wright JL: Cigarette smoke drives small airway remodeling by induction of growth factors in the airway wall. Am J Respir Crit Care Med 2006, 174: $1327-1334$

22. Bartalesi B, Cavarra E, Fineschi S, Lucattelli M, Lunghi B, Martorana PA, Lungarella G: Different lung responses to cigarette smoke in two strains of mice sensitive to oxidants. Eur Respir J 2005, 25:15-22

23. De Cunto G, Cardini S, Cirino G, Geppetti P, Lungarella G, Lucattelli M: Pulmonary hypertension in smoking mice overexpressing protease-activated receptor-2. Eur Respir J 2011, 37: 823-834

24. Cardini S, Dalli J, Fineschi S, Perretti M, Lungarella G, Lucattelli M: Genetic ablation of the Fprl gene confers protection from smokinginduced lung emphysema in mice. Am J Respir Cell Mol Biol 2012, 47:332-339

25. Stockley RA, Grant RA, Llewellyn-Jones CG, Hill SL, Burnett D: Neutrophil formyl-peptide receptors. Relationship to peptide-induced responses and emphysema. Am J Respir Crit Care Med 1994, 149: 464-468

26. Dorward DA, Lucas CD, Doherty MK, Chapman GB, Scholefield EJ, Conway Morris A, Felton JM, Kipari T, Humphries DC, Robb CT, Simpson AJ, Whitfield PD, Haslett C, Dhaliwal K, Rossi AG: Novel role for endogenous mitochondrial formylated peptide-driven formyl peptide receptor 1 signalling in acute respiratory distress syndrome. Thorax 2017, 72:928-936

27. Martorana PA, Beume R, Lucattelli M, Wollin L, Lungarella G: Roflumilast fully prevents emphysema in mice chronically exposed to cigarette smoke. Am J Respir Crit Care Med 2005, 172:848-853

28. Cosio M, Ghezzo H, Hogg JC, Corbin R, Loveland M, Dosman J, Macklem PT: The relations between structural changes in small airways and pulmonary-function tests. N Engl J Med 1978, 298: $1277-1281$

29. Hasegawa M, Nasuhara Y, Onodera Y, Makita H, Nagai K, Fuke S, Ito Y, Betsuyaku T, Nishimura M: Airflow limitation and airway dimensions in chronic obstructive pulmonary disease. Am J Respir Crit Care Med 2006, 173:1309-1315

30. World Medical AssociationAmerican Physiological Society: Guiding principles for research involving animals and human beings. Am J Physiol Regul Integr Comp Physiol 2002, 283:R281-R283

31. Cavarra E, Bartalesi B, Lucattelli M, Fineschi S, Lunghi B, Gambelli F, Ortiz LA, Martorana PA, Lungarella G: Effects of cigarette smoke in mice with different levels of alpha(1)-proteinase inhibitor and sensitivity to oxidants. Am J Respir Crit Care Med 2001, 164:886-890

32. Atzori L, Lucattelli M, Scotton CJ, Laurent GJ, Bartalesi B, De Cunto G, Lunghi B, Chambers RC, Lungarella G: Absence of proteinase-activated receptor-1 signaling in mice confers protection from fMLP-induced goblet cell metaplasia. Am J Respir Cell Mol Biol 2009, 41:680-687

33. Lucattelli M, Fineschi S, Selvi E, Garcia Gonzalez E, Bartalesi B, De Cunto G, Lorenzini S, Galeazzi M, Lungarella G: Ajulemic acid exerts potent anti-fibrotic effect during the fibrogenic phase of bleomycin lung. Respir Res 2016, 17:49

34. Winer J, Jung CK, Shackel I, Williams PM: Development and validation of real-time quantitative reverse transcriptase-polymerase chain reaction for monitoring gene expression in cardiac myocytes in vitro. Anal Biochem 1999, 270:41-49

35. Pahl HL: Activators and target genes of Rel/NF-kappaB transcription factors. Oncogene 1999, 18:6853-6866

36. Hol J, Wilhelmsen L, Haraldsen G: The murine IL-8 homologues KC, MIP-2, and LIX are found in endothelial cytoplasmic granules but not in Weibel-Palade bodies. J Leukoc Biol 2010, 87:501-508

37. Menten P, Wuyts A, Van Damme J: Macrophage inflammatory protein-1. Cytokine Growth Factor Rev 2002, 13:455-481

38. Lunghi B, De Cunto G, Cavarra E, Fineschi S, Bartalesi B, Lungarella G, Lucattelli M: Smoking p66Shc knocked out mice develop respiratory bronchiolitis with fibrosis but not emphysema. PLoS One 2015, 10:e119797

39. Yu C, Wang F, Jin C, Huang X, Miller DL, Basilio C, McKean WL: Role of fibroblast growth factor type 1 and 2 in carbon tetrachloride-induced hepatic injury and fibrogenesis. Am J Pathol 2003, 163:1653-1662

40. Hautamaki RD, Kobayashi DK, Senior RM, Shapiro SD: Requirement for macrophage elastase for cigarette smoke-induced emphysema in mice. Science 1997, 227:2002-2004

41. Atherton HC, Jones G, Danahay H: IL-13-induced changes in goblet cell density of human bronchial epithelial cell cultures: MAP kinase and phosphatidylinositol 3-kinase regulation. Am J Physiol Lung Cell Mol Physiol 2003, 285:L730-L739

42. Dorward DA, Lucas CD, Chapman GB, Haslett C, Dhaliwal K, Rossi AG: The role of formylated peptides and formyl peptide receptor 1 in governing neutrophil function during acute inflammation. Am $\mathrm{J}$ Pathol 2015, 185: $1172-1184$

43. Chen K, Bao Z, Gong W, Tang P, Yoshimura T, Wang JM: Regulation of inflammation by members of the formyl-peptide receptor family. J Autoimmun 2017, 85:64-77

44. Gao JL, Chen H, Filie JD, Kozak CA, Murphy PM: Differential expansion of the $\mathrm{N}$-formylpeptide receptor gene cluster in human and mouse. Genomics 1998, 51:270-276

45. Le Y, Yang Y, Cui Y, Yazawa H, Gong W, Qui C, Wang JM: Receptors for chemotactic formyl peptides as pharmacological targets. Int Immunopharmacol 2002, 2:1-13

46. Rabiet MJ, Huet E, Boulay F: Human mitochondria-derived N-formylated peptides are novel agonists equally active on FPR and FPRL1, while Listeria monocytogenes-derived peptides preferentially activate FPR. Eur J Immunol 2005, 35:2486-2495

47. Grommes J, Drechsler M, Soehnlein O: CCR5 and FPR1 mediate neutrophil recruitment in endotoxin-induced lung injury. J Innate Immun 2014, 6:111-116

48. Hasday JD, Bascom R, Costa JJ, Fitzgerald T, Dubin W: Bacterial endotoxin is an active component of cigarette smoke. Chest 1999, 115: $829-835$

49. Cavarra E, Martorana PA, de Santi M, Bartalesi B, Cortese S, Gambelli F, Lungarella G: Neutrophil influx in the lung of beige mice is followed by elastolytic damage and emphysema. Am J Respir Cell Mol Biol 1999, 20:264-269 